\title{
Investigation of antiscalant dosing influence on scaling process in reverse osmosis facilities and membrane surface adsorption
}

\author{
Val S. Frenkel ${ }^{1}$, Alexey G. Pervov ${ }^{2}$, Alexey P. Andrianov ${ }^{2}$, Vladimir A. Golovesov ${ }^{2}$ \\ ${ }^{1}$ GREELEY and HANSEN, 50 California st., suite 1500, San Francisco, California 94111, USA; \\ ${ }^{2}$ Moscow State University of Civil Engineering (National Research University) (MGSU), \\ 26 Yaroslavskoe shosse, Moscow, 129337, Russian Federation
}

\begin{abstract}
Introduction. Understanding of crystal growth mechanism enables to develop efficient tools to control scaling and improve the process of treatment using membranes and increasing the amount of filtrate output. This investigation is aimed at studying an antiscalant behaviour in reverse osmosis (RO) process when treating ground water. Experimental dependences of calcium carbonate scaling efficiency on antiscalant dosage were found. Rates of adsorption on crystal surface of scaling deposit and on membrane surfaces were compared. Dependences of rates of inhibitor adsorption on crystal surface versus scaling rates were determined. Inhibitor adsorption on RO membrane surfaces was studied. New approaches to studying crystal growth mechanism in the presence of polymeric inhibitors are presented.

Materials and methods. In the course of experiments conducted with using inhibitor dissolved in distilled water, inhibitor sorption on membrane surface was observed in the absence of calcium ions. As to experiments with dosing the inhibitor in tap water, the inhibitor sorption on the membrane did not occur: the inhibitor was adsorbed on the surface of the scaling crystals. Results. Experimental relationships are obtained that show dependencies of calcium carbonate deposit growth rates versus RO facility filtrate output values in the presence of different antiscalants with their dose values of 3,5 and $7 \mathrm{mg} / \mathrm{l}$. The article shows that antiscalant dose value does not provide substantial influence on antiscalant efficiency when natural water with low hardness is treated in the RO facility. This permits substantial reduction of operational costs. It was also proved that inhibitor is not adsorbed on membrane surface during natural water treatment that also confirms efficiency of low antiscalant dosing. Conclusions. Low hardness values of natural water (3-5 mill equivalents per liter) demonstrate that antiscalant efficiencies do not depend on its dose. Rate of inhibitor adsorption on crystal surface during calcium carbonate deposition also increases with scaling rate increase. Rates of antiscalant consumption increase with antiscalant dose values. In natural water the dissolved antiscalant molecules are bonded with calcium ions therefore antiscalant does not react with membranes and is not adsorbed on membrane surface.
\end{abstract}

KEYWORDS: reverse osmosis, calcium carbonate, crystalline deposits on membranes, inhibitors, crystal growth, heterogeneous nucleation, inhibitor adsorption

Acknowledgements. The authors would like to express their gratitude to Russian Foundation of Basic Research that supported investigations on development of fluorescent antiscalants and visualization tools by research grant No. 17-08-00061. Research on evaluation of antiscalant efficiency and adsorption properties were supported by RFBR grant No. 19-08-00982.

FOR CITATION: Frenkel V.S., Pervov A.G., Andrianov A.P., Golovesov V.A. Investigation of antiscalant dosing influence on scaling process in reverse osmosis facilities and membrane surface adsorption. Vestnik MGSU [Proceedings of Moscow State University of Civil Engineering]. 2019; 14(6):722-733. DOI: 10.22227/1997-0935.2019.6.722-733

\section{Изучение влияния дозирования ингибитора на процесс осадкообразования в установках обратного осмоса и адсорбции на поверхности мембран}

\author{
Вал С. Френкель ${ }^{1}$, А.Г. Первов ${ }^{2}$, А.П. Андрианов ${ }^{2}$, В.А. Головесов² \\ ${ }^{1}$ Грили и Хансен, 94111, США, Калифорния, г. Сан-Франциско, ул. Калифорния, д. 50, оф. 1500; \\ ${ }^{2}$ Национальный исследовательский Московский государственный строительный университет
} (НИУ МГСУ), 129337, г. Москва, Ярославское шоссе, д. 26

\begin{abstract}
АННОТАЦИЯ
Введение. Знание механизма роста кристаллов позволяет разработать эффективные методы борьбы с осадкообразованием и совершенствовать процесс очистки с использованием мембран, увеличивая величину выхода фильтрата. Цели исследования - изучение поведения ингибитора во время процесса обратного осмоса при обработке подземных вод; экспериментальное определение эффрективностей образования осадка карбоната кальция в зависимости
\end{abstract}


от дозы ингибитора; определение скоростей сорбции ингибитора на поверхности кристаллов образующегося осадка; определение зависимостей скоростей адсорбции ингибитора на кристаллах от скоростей осадкообразования; исследование адсорбции ингибиторов на поверхности обратноосмотических мембран.

Представлены новые подходы к изучению механизма роста кристаллов в присутствии полимерных ингибиторов.

Материалы и методы. В процессе экспериментов, проведенных с использованием растворов ингибитора в дистиллированной воде, наблюдалась сорбция ингибитора на поверхности мембраны в отсутствие ионов кальция. В экспериментах, в которых ингибитор дозировался в исходную водопроводную воду, сорбции ингибитора на мембране не происходило: ингибитор адсорбировался на поверхности образующихся кристаллов.

Результаты. Получены экспериментально определенные зависимости скоростей роста осадка карбоната кальция от величины выхода фильтрата установки обратного осмоса при использовании различных ингибиторов осадкообразования и при различных дозах ингибиторов, составлявших 3, 5 и 7 мг/л. Показано, что при невысоких значениях жесткости обрабатываемой воды доза ингибитора не оказывает влияния на эффективность ингибирования, что позволяет существенно сократить эксплуатационные затраты. Установлено, что ингибитор не адсорбируется на поверхности мембран в процессе обработки природных вод, что подтверждает возможность поддержания низкой дозы ингибитора. Выводы. При невысоких значениях жесткости исходной обрабатываемой воды (3-5 мг-экв/л) эфрфективность ингибитора не зависит от дозы. Скорость адсорбции ингибитора на поверхностях кристаллов образующегося осадка растет с ростом скорости осадкообразования. Скорость поглощения ингибитора растет с увеличением дозы ингибитора. Ингибитор в природной воде находится в связанном состоянии с ионами кальция, поэтому не реагирует с мембранами и не адсорбируется на их поверхности.

КЛЮчЕВЫЕ СЛОВА: обратный осмос, карбонат кальция, кристаллические отложения на мембранах, ингибиторы, рост кристаллов, гетерогенное зародышеобразование, адсорбция ингибитора

Благодарности. Авторы выражают благодарность РФФИ, поддержавшему исследования по разработке фрлуоресцентных антискалантов и средств визуализации по гранту № 17-08-00061. Исследования по оценке эффеективности антискалантов и их адсорбционных свойств были поддержаны грантом РФФИ № 19-08-00982.

для цитИРовАния: Френкель В.С., Первов А.Г., Андрианов А.П., Головесов В.А. Investigation of antiscalant dosing influence on scaling process in reverse osmosis facilities and membrane surface adsorption // Вестник МГСУ. 2019. T. 14. Вып. 6. С. 722-733. DOI: 10.22227/1997-0935.2019.6.722-733

\section{INTRODUCTION}

Scaling of sparingly soluble salts could be recognized as a main factor that limits wide application of RO membrane facilities in drinking water production and industrial water recycling. A lot of research was undertaken to understand main reasons that cause scaling to predict this process and outline measures for its prevention and control. A critical review of research articles devoted to investigation of scaling mechanisms reveals that the problem is rather far from the solution $[1,2]$. Development of scale prevention tools needs understanding of crystal formation and inhibition mechanisms. A lot of research was devoted to investigation of inhibition of crystal growth using various antiscalants. The majority of these research experiments and their conclusions were based on experimental results of beaker tests performed in laboratory conditions [1-18]. It was already reported that scale formation conditions in the beaker tests often does not correspond to real conditions in industrial membrane modules. Thus, it is still unknown, what are the super saturation values of crystal nucleation, what are the crystal growth rates and, finally, why membrane product flow and rejection decrease during scaling process?

The existing views on scaling mechanisms are based on assumption that "active sites" exist on membrane surface that facilitate nucleation. Therefore nucleation is heterogeneous and takes place on membrane surface [19-21]. Prediction of scale formation by antiscalant addition follows mechanism of adsorption of antiscalant on these "sites" and suppression of their activities. Different interpretation of these views is discussed in publications of many authors. Different experimental approaches to evaluate antiscaling efficiencies can be explained by different views on the scaling process conditions [19-21].

Nucleation and crystal growth rates are still unknown and chemical community still cannot detect formation of crystals and calculate super saturation values inside the "dead areas". These seem very important as scaling control tools (such as inhibition) should be evaluated in real conditions that correspond to super saturation values that exist in commercial membrane modules. This fact should be accounted when antiscalant tests are conducted to introduce "green" antiscal- 
ants into RO application practice [22-34]. The lack of efficient experimental test procedure that provides real super saturation and crystal growth conditions often gives inconsistent results of antiscalant testing's.

Experimental procedure and scaling conditions should correspond to super saturation values in membrane channels. Therefore, antiscalant efficiencies should be tested under real super saturation conditions under which crystals are formed, grow and build scaling layers. Unfortunately the majority of research present results of antiscalant testing are obtained under conditions that do not correspond to real conditions that exist in membrane modules. Many conclusions are based on resuls of experimental procedure that consisted of "seed crystals" addition into supersaturated solution [1-7]. As it was shown before [24], the values of crystal growth and antiscalant adsorption obtained under experimental conditions with low super saturations do not correspond to real conditions of scaling process in membrane modules. Nevertheless, results of seed experiments helped to develop main relationships between crystal growth rates and super saturation values in the presence of different antiscalants. But until now lot of inconveniences exist that are based on the results of research conducted using "seed growth" techniques. Prediction techniques proposed by many commercial antiscalant producing companies recommend different doses of antiscalants that depend on water hardness [17, 18]. Meanwhile, as it was claimed by the authors in [24], antiscalant dose does not influence scaling intensiveness at low hardness values. This can be explained that crystal formation occurs in "dead areas" where calcium and bicarbonate and inhibitor concentration reach high values under high super saturation conditions. A number of research conducted by the authors of present article is devoted to investigations of "dead areas" and conditions of crystal formation $[24,26]$.

Basing on results of conducted research, main understandings of scaling mechanisms were postulated:

- nucleation is homogeneous and occurs in "dead areas" where super saturations reach high values;

- crystals are formed in "dead areas", get out of these areas and finally sediment on membrane surface.

During last year's new antiscalants are developed that use fragments built in antiscalant polymer structure $[25,26,33]$. Thus new opportunities are opened to "visualize" inhibiting process. First investigations of gypsum crystallization using antiscalants revealed many disadvantages of modern theoretical mechanism that need revision [26]. It seems very interesting to "visualize" antiscalant behavior in industrial conditions during RO spiral wound elements operation.

The goal of the present article was to investigate behavior of antiscalants, both conventional: sorption of inhibitors on crystal surface and investigate influ- ence of sorption abilities on antiscaling properties. The test procedure was developed by the authors $[24,26]$ that enabled us to determine scaling rates in industrial membrane spiral wound modules under variety of conditions.

\section{EXPERIMENTS}

Conventionally used phosphoric antiscalant "Aminat-K" produced by "Traverse Co"(Russia) and acrylic antiscalant AMETEK-RO2 were used in experiments. "Aminat-K" is a composition of nitrilitri-methylenephosphonic acid and imino-dimethylene-phosphonic acid [27]. AMETEK-RO2 is an aqueous solution of short-chain sodium polyacrylate with molecular mass of $400 \mathrm{Da}$ [27].

The experimental procedure included both RO facility tests conducted in conformity with procedure developed by the authors [24].

Adsorption rates of antiscalants on membrane surface were evaluated and presented as a function of crystal growth rates. Also antiscalant adsorption on membrane surface was tested as well as the influence of of membrane surface on sorption efficiency. To reach this goal, along with calcium carbonate scaling rates, rates of inhibitor adsorption on scale crystals during its formation were determined. Further investigation of sorption of inhibitor on membrane surface and on the surface of already formed scale crystals enables us to conclude that antiscalant can adsorb eighther on membrane surface or crystal surface. Inhibitor sorption rate can characterise antiscalant efficiency. Application of antiscalant provides control of antiscalant concentration in solution during scaling process.

Experimental program consisted of three experimental series:

Series 1: Evaluation of calcium carbonate scaling rates in spiral wound membrane industrial module in the presence of conventional "Aminat-K" antiscalant with dosage values of 3,5 and $7 \mathrm{ppm}$;

Series 2: Evaluation of calcium carbonate scaling rates in membrane module using newly developed antiscalant AMETEK RO-2 with dosage values of 3, 5 and 7 ppm;

Series 3: Evaluation of antiscalant adsorption rates to membrane surface in the absence of calcium carbonate scaling.

All experiments were conducted using laboratory membrane test unit. A flow diagram of the test unit is shown on Figure 1. The test unit was operated in circulation mode whereby concentrate after membrane module was returned back to feed water tank. The feed water was added to feedwater tank 1 . The volume of tank 1 was 5 liters. Feed water from tank 1 was supplied by small gear pump 2 to membrane module 3 . 
In all experiments industrial spiral wound modules of 1812 standard with 100 GPD capacities were used. The module used low pressure reverse osmosis membranes BLN type developed and manufactured by CSM Co (Korea). Membrane area in 1812 membrane element was 0, 5 square meters. Pressure value and concentrate flow rate were regulated by pressure regulation valve 12. Concentrate stream after membrane module was returned back to feed water tank 1 and product water stream was collected in separate tank 4 or discharged in drain. Working pressure volume in membrane module was maintained at the level of 7 Bars. The volume of concentrate that circulated in feed water tank was determined using marks on transparent walls of the tank 1 . Concentrate water samples were withdrawn from the tank 1 and product water samples were taken directly from product water tube.

The samples were tested and temperature, unit conductivity, $\mathrm{pH}$ as well as hardness, calcium, bicarbonate concentration values were determined. Conductivity and total dissolved solids values were controlled using laboratory conductivity meter Cond 730 (WTW inoLab), and $\mathrm{pH}$ values were determined using laboratory pH-meter HI 2215 (HannaInstruments). Bicarbonate, hardness and calcium concentration values were determined by titration.

To remove calcium carbonate deposits accumulated on membranes during test runs, we applied chemical cleanings of membranes between different series conduction using $2 \%$ citric acid solution. To prepare cleaning solution tap water was used. Cleaning procedures were performed using the pump 2 . Both the first and the second experimental series were conducted using the same membrane element BLN 1812. As it was presented and discussed earlier in [22], all comparison studies of scaling rates and antiscalant efficiencies determination should be performed using one membrane element: different membrane elements have different amount of "dead" areas and therefore poses different scaling propensities at equal operation conditions.

Concentration of "Aminat-K" antiscalant was controlled by determination of phosphate-ion concentration values in conformity with the method described in [28] Concentration of new antiscalant in concentrate was controlled by fluorescence determination. First and second experimental series were conducted using Moscow tap water as feed water. The volume of feed water in tank 1 in the beginning of each experiment was 5 liters. Product flow of membrane element BLN 1812 throughout each experiment test run was 6-6, 3 liters per hour that depended on temperature value. Moscow tap water TDS value was 240-260 ppm. Total hardness was 3.1-3.4 mill equivalents per liter, bicarbonate was 2.8-3.1 mill equivalents per liter, calcium concentration was 2.8-3.1 mill equivalents per liter. Chloride concentration was $28-30 \mathrm{ppm}$ and sulphate was $10-13 \mathrm{ppm}$.

The amount of calcium carbonate deposited on membrane surface during test run was determined as a difference between calcium amount in tank 1 in the beginning of experiment and amount of calcium in the feed tank at the certain moment of the test run [22]. Figure 2 shows experimental relationships of: calcium concentration versus $\mathrm{K}$ value (Fig. 2, $a$ ) and calcium carbonate amount versus $\mathrm{K}$ (Fig. 2, b). Calcium carbonate growth rates were evaluated in conformity with our method described in [22] and were determined as tan-

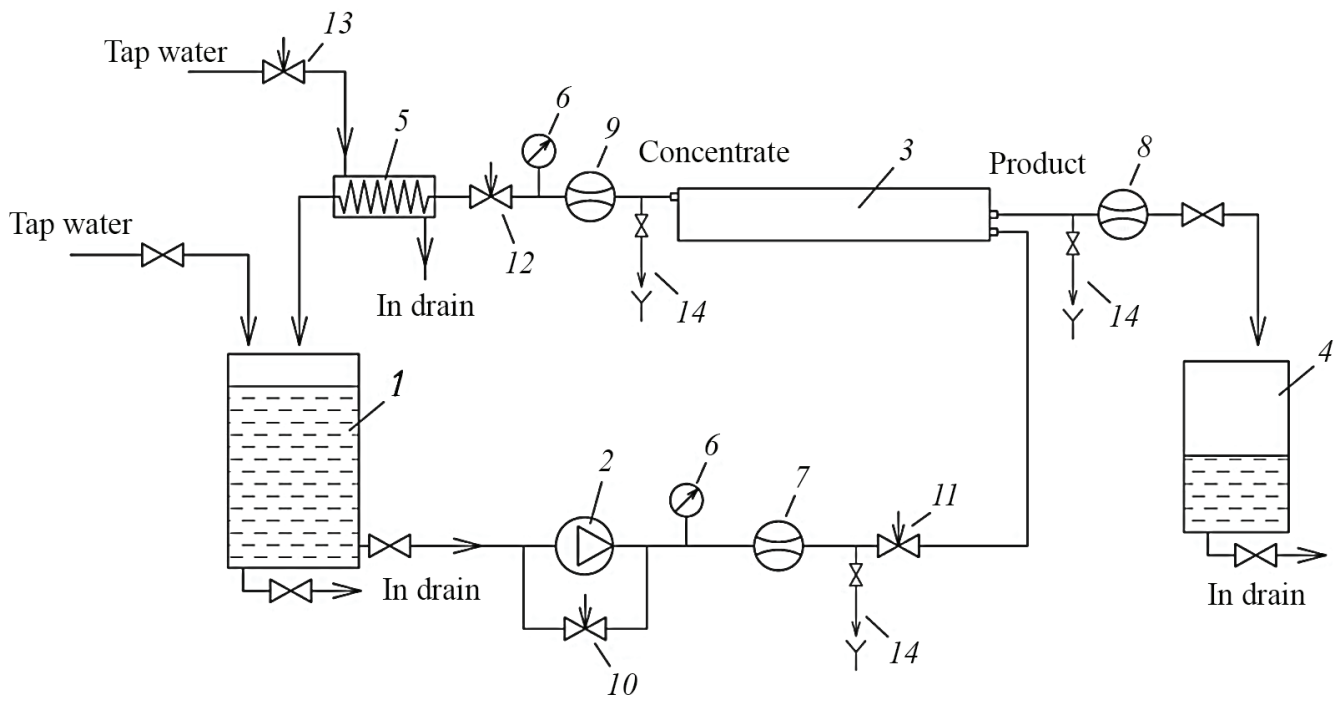

Fig. 1. Schematic diagram of laboratory RO unit for membrane scaling tests: 1 - feed water tank; 2 - pump; 3 - spiral wound membrane module; 4 - permeate tank; 5 - heat exchanger; 6 - pressure gauge; 7 - feed water flow meter; 8 permeate flow meter; 9 - concentrate flow meter; 10 - by-pass adjusting valve; 11 - feed water adjusting valve; 12 - concentrate adjusting valve; 13 - cooling water adjusting valve; 14 - sampler 


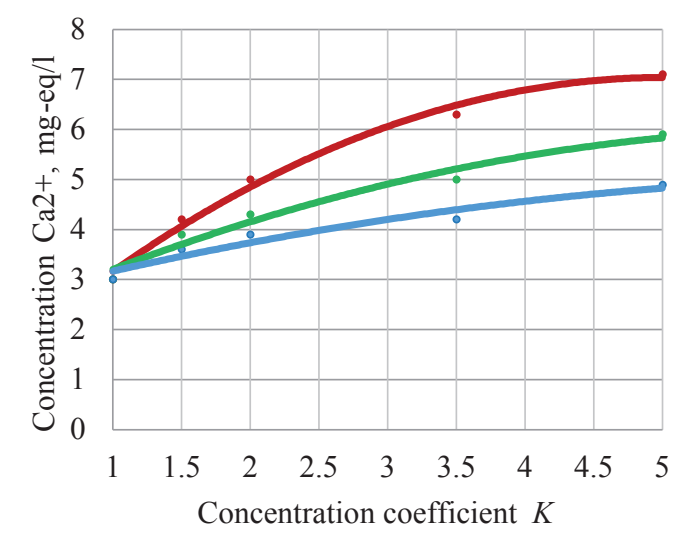

- Aminat K, 3,5,7ppm

- Without of antiscalant

$a$

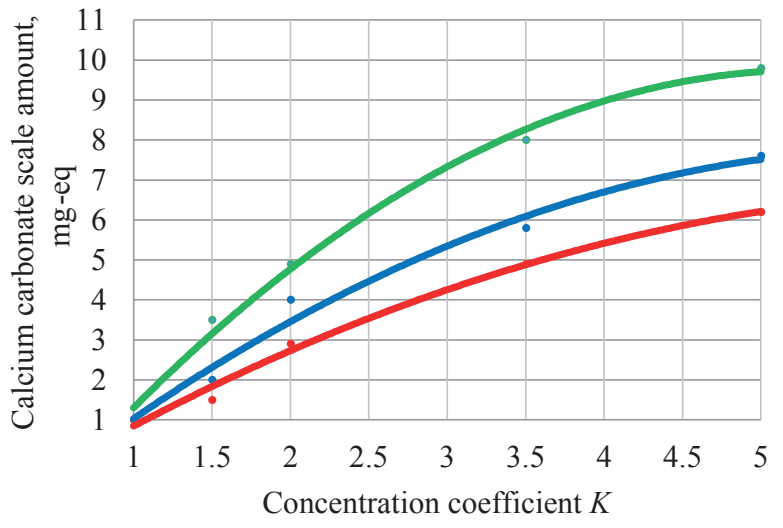

- Without of antiscalant

- PAA-F1, 3, 5, 7 ppm

- Aminat K, 3,5,7 ppm

$b$

Fig. 2. Determination of antiscalig efficiencies: $a$ - calcium ion concentration values versus $\mathrm{K} ; b$ - amount of accumulated calcium carbonate versus K: 1 - antiscalant Aminat-K; 2 - antiscalant PAA-F-1; 3 - without antiscalant. Antiscalant doses: 3 ppm; 5 ppm; 7 ppm

gents of the slope of curves that yield calcium carbonate scale amount versus time (Fig. 3, a). Results of calcium carbonate growth rate determination are presented on fig. $3, b$ as dependencies of scaling rates (expressed in mill equivalents per hour) on concentration coefficient $K$ values. $K$ is determined as the volume in tank 1 reduction ratio: the ratio of the volume in tank 1 in the beginning of experiment to the volume in the certain moment of experiment. The volume of concentration coefficient $K$ is a function of membrane unit Recovery value a (product flow to feed water flow ratio) expressed by equation: $K=1 / 1-\alpha$.

During the first and the second experimental series conductance along with calcium carbonate growth rates evaluation also rates of inhibitor adsorption (or

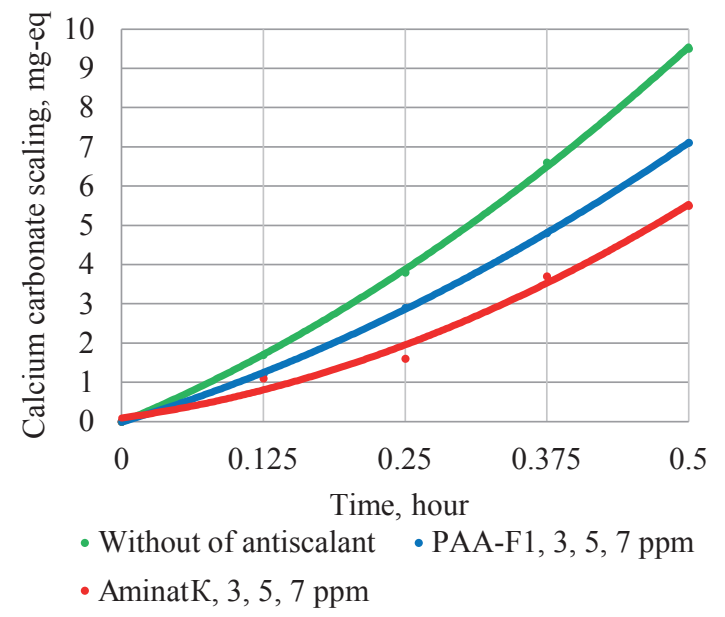

accumulation in membrane module) were determined. The amount of adsorbed antiscalant was evaluated as the difference of antiscalant amount in the tank 1 in the beginning of experiment and amount of antiscalant in tank 1 in the certain moment of experiment. Both "Aminat-K" and AMETEK RO-2were tested, and doses of each antiscalant were 3, 5 and $7 \mathrm{ppm}$. Additionally each series included three test runs to evaluate how amount of accumulated calcium carbonate influences inhibitor adsorption on membrane surface and on the surface of already formed crystals. Fig. 4 shows results of determination of antiscalants adsorption rates versus $\mathrm{K}$ values. Adsorption rate values do not increase with the growth of deposited calcium carbonate: antiscalant was consumed only by forming crystals. Also results of ad-

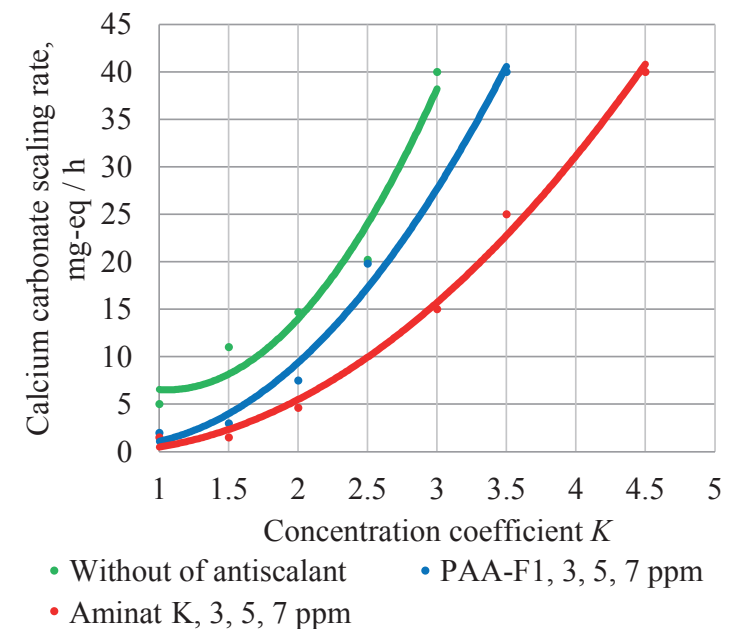

Fig. 3. Determination of scaling rates in the presence of antiscalants: $a$ - calcium carbonate amount versus time of operation; $b$ - calcium carbonate scaling rates versus $\mathrm{K}$ 

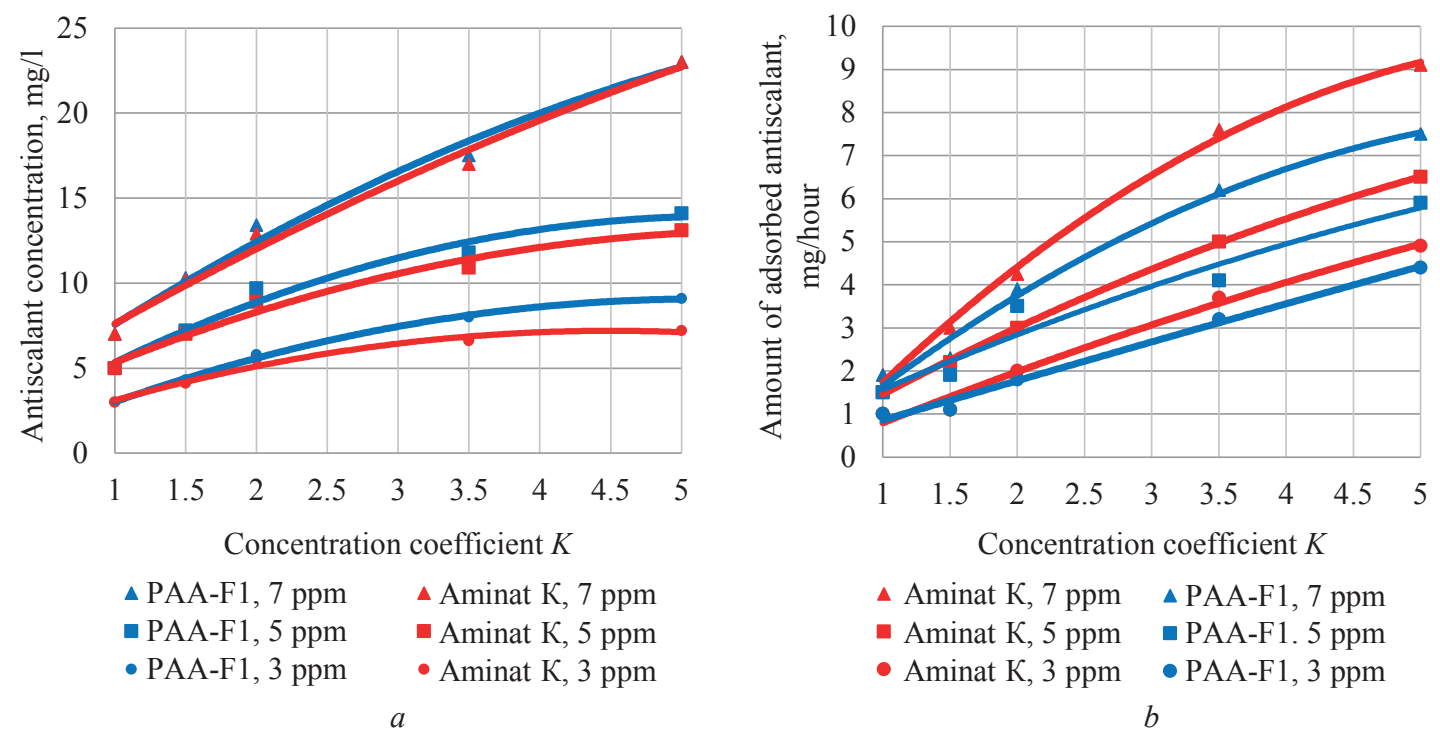

$\Delta$ Aminat $\mathrm{K}, 7 \mathrm{ppm} \quad \triangle \mathrm{PAA}-\mathrm{F} 1,7 \mathrm{ppm}$

- Aminat K, 5 ppm $\quad$ PAA-F1. 5 ppm

- Aminat K, 3 ppm $\bullet$ PAA-F1, 3 ppm
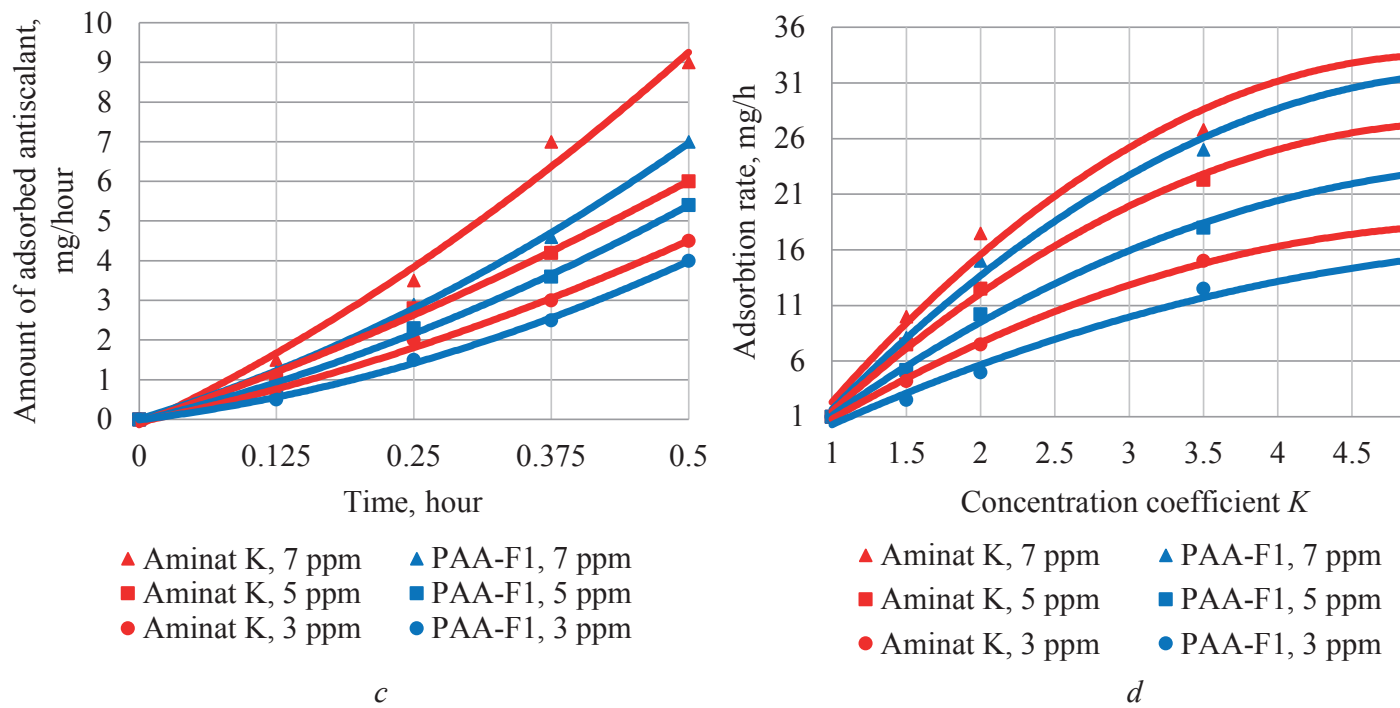

$\begin{array}{ll}\triangle \text { Aminat } \mathrm{K}, 7 \mathrm{ppm} & \triangle \mathrm{PAA}-\mathrm{F} 1,7 \mathrm{ppm} \\ \text { - Aminat K, } 5 \mathrm{ppm} & \text { PAA-F1,5 ppm } \\ \text { - Aminat K, } 3 \mathrm{ppm} & \text { - PAA-F1,3 ppm }\end{array}$ sorption rates determination are presented as functions of calcium carbonate growth rates (Fig. 5) and antiscalant dose at scaling rate value of $10 \mathrm{mg} /$ hour (Fig. 6).

The third experimental series was devoted to investigation of antiscalant adsorption on membrane surface. Experiments were conducted with the aim to exclude influence of calcium carbonate crystals on antiscalant behavior in the feed water solution. Experiments were conducted using laboratory test unit shown on Figure 1 in full circulation mode. As a difference to Series 1 and 2, in Series 3 experiments product water flow was also returned back to feed water tank 1. As it was claimed and discussed in a number of publication devoted to carbonate system studies [1, 18, 19, 24], calcium carbonate is not deposited in a "closed" conditions even under high initial super saturation values: deposition of even small amount of calcium carbonate is followed by change of $\mathrm{pH}$ and carbonate ion concentration values. To initiate calcium carbonate deposition during experimental test run, a "driving force" (i.e. super saturation) should be applied to increase calcium and carbonate concentration values as well as $\mathrm{pH}$ value. Therefore, operation of the test unit in circulation mode does not provide calcium carbonate deposition in membrane module and antiscalant can be adsorbed only on membrane surface. Fig. 7 demonstrates dependencies of antiscalant concentration values in feed water tank versus time and results of adsorption rates determination. Adsorption rates rapidly decrease in the first minutes of feed water circulation (Fig. 7). Fig. 8 shows results of determination of calcium carbonate scaling rates $(b)$ in the beginning of experiment and inhibitor sorption rates versus its dose $(c)$. A new experimental test run was performed using distilled water as a feed water. AM- 


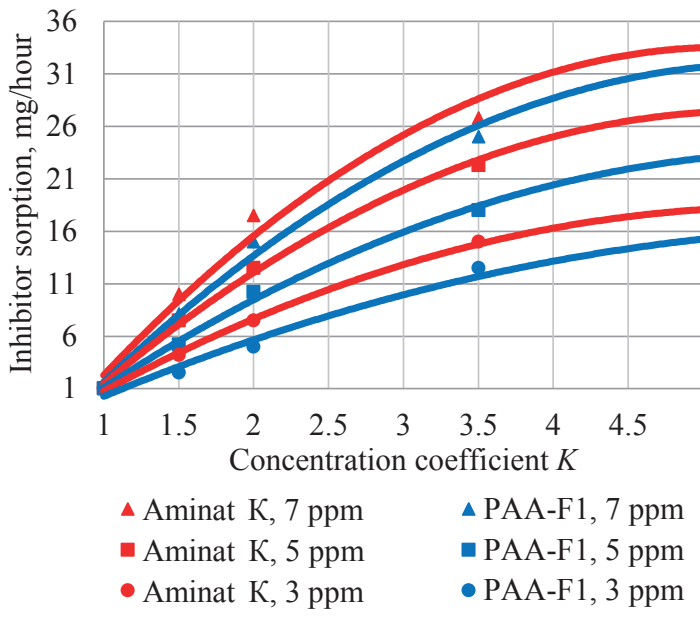

Fig. 5. Dependencies of inhibitor sorption rates versus scaling rate values
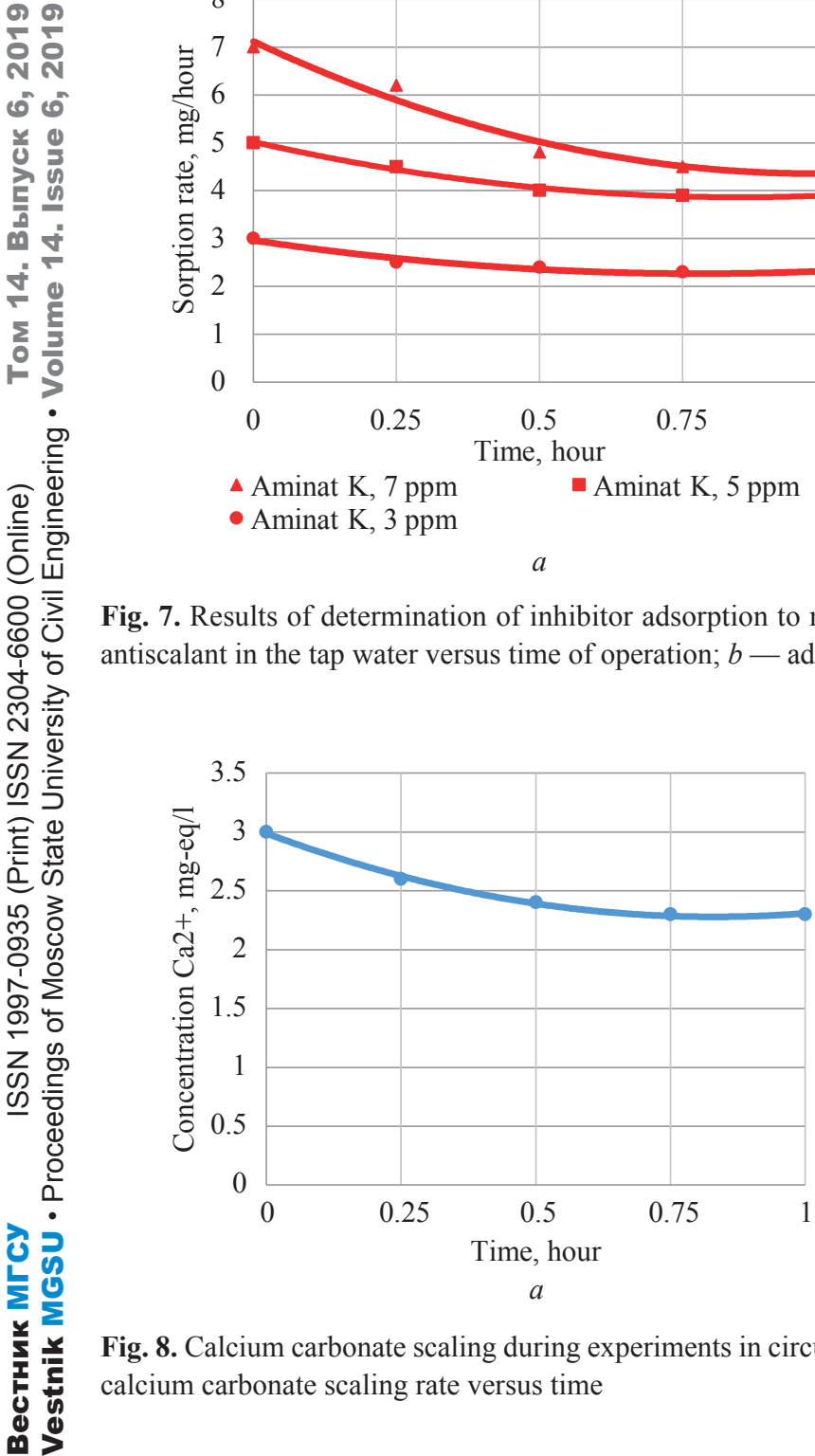
calcium carbonate scaling rate versus time

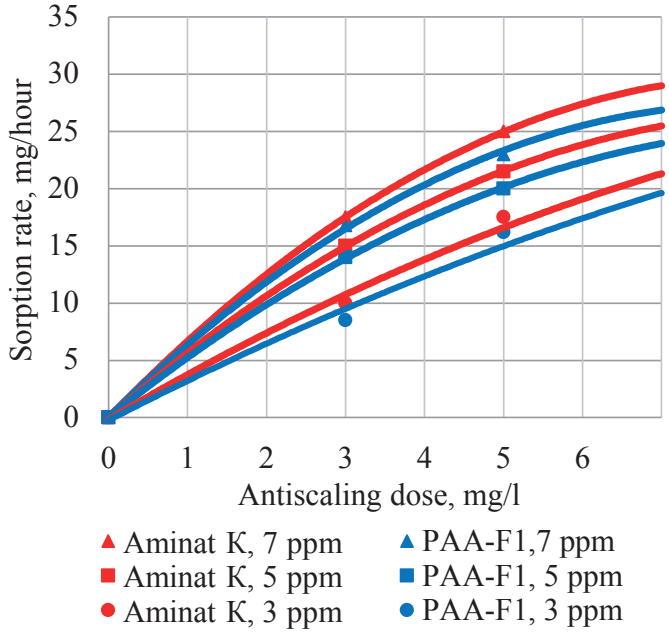

Fig. 6. Sorption rate values as a function of antiscalant dose (for the scaling rate value 10 mill equivalents per hour)

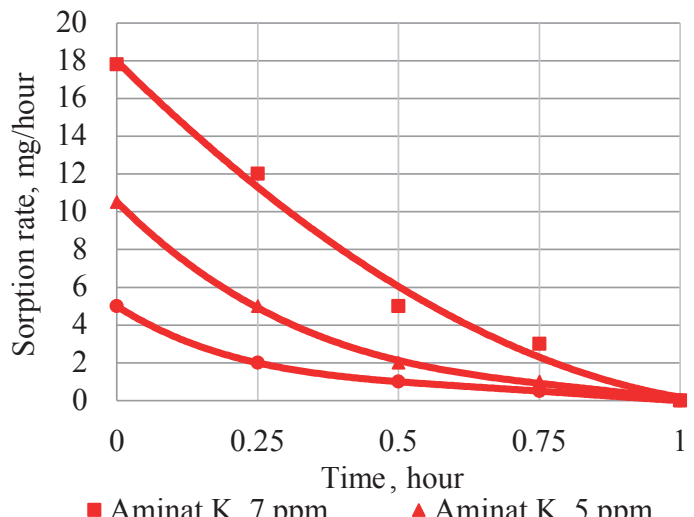

- Aminat $\mathrm{K}, 7 \mathrm{ppm} \quad \Delta$ Aminat $\mathrm{K}, 5 \mathrm{ppm}$

- Aminat K, 3 ppm

$b$

Fig. 7. Results of determination of inhibitor adsorption to membrane (experiments with a tap water): $a$ - concentration of antiscalant in the tap water versus time of operation; $b$ - adsorption rate values versus $\mathrm{K}$

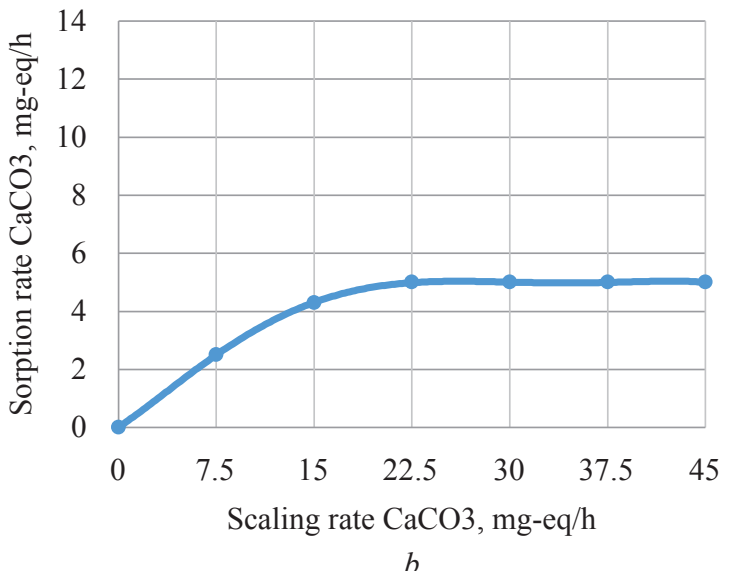

Fig. 8. Calcium carbonate scaling during experiments in circulation mode: $a$ - calcium concentration decrease with time; $b$ - 


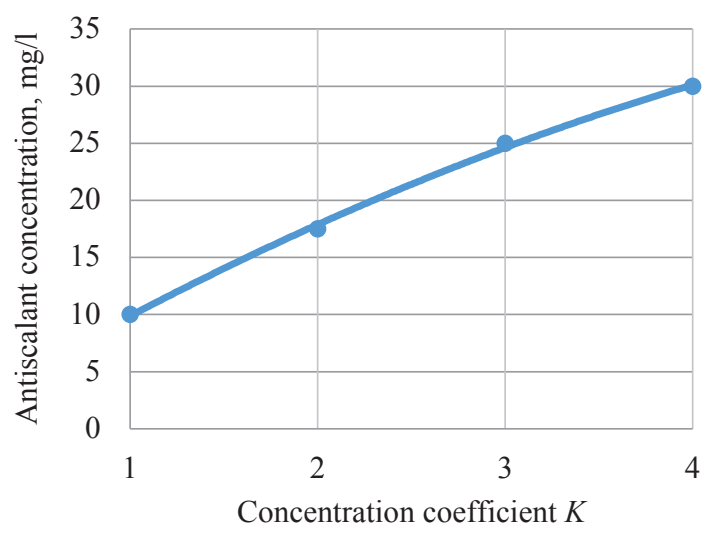

$a$

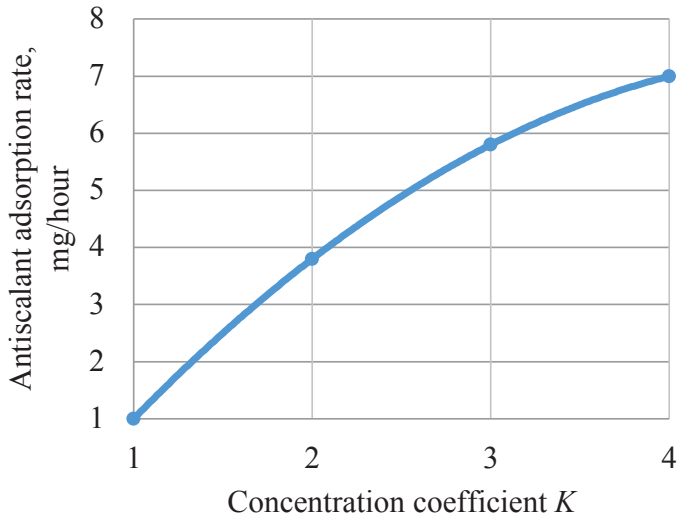

$b$

Fig. 9. Determination of inhibitor adsorption rates (distilled water experiments): $a$ - antiscalant concentration versus $\mathrm{K} ; b-$ adsorbed antiscalant amount versus $\mathrm{K}$

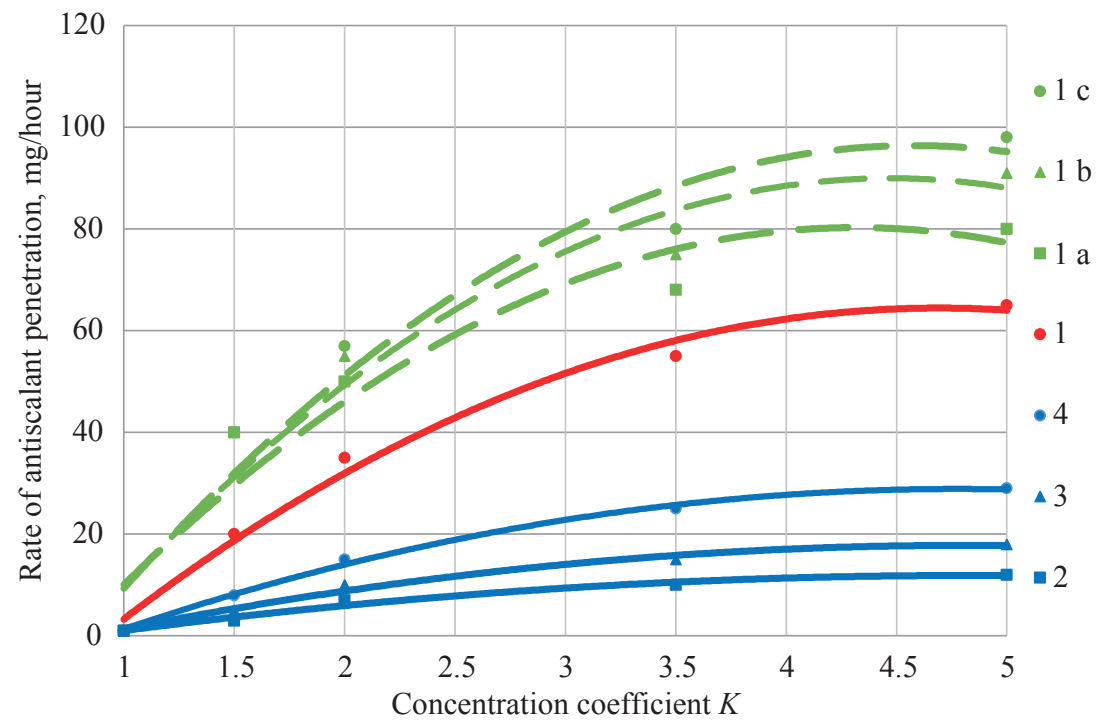

Fig. 10. Results of antiscalant behavior after treatment of membrane with antiscalant solution in distilled water

ETEK RO-2antiscalant concentration in distilled water was 10 ppm. Fig. 9 shows results of determination of antiscalant amount adsorbed on membrane surface. After antiscalant adsorption on membrane surface was detected, it was decided to evaluate calcium carbonate scaling rates in the module treated by antiscalant. Results of scaling rates determination and antiscalant behavior are shown on Fig. 10.

Experimental results illustrated by figures 9 and 10 confirm our assumption that antiscalant adsorbed on membrane surface after treatment of membrane with antiscalant solution in distilled water. AMETEK RO-2 antiscalant accumulated on membrane surface and later penetrated in the tap water and inhibited calcium carbonate growth. After the second and the third experimental series were finished, membrane element autopsies were performed.
Experiments conducted with industrial membrane modules demonstrated that formation of scale occurs under conditions that often differ from conditions of laboratory tests. Thus one has a right to question the validity of beaker tests normally used for the "true" inhibitor selection for RO facilities. By all means an application of the direct determination of antiscalant adsorption rates may put light on many aspects of scale inhibitor applications.

\section{CONCLUSIONS}

1. The higher is antiscalant dose in the feed water; the more intensive is its adsorption rate on crystal surface. Weak antiscalant is adsorbed with lower rate than strong antiscalant at the equal scaling formation conditions. 
2. Inhibiting efficiency of antiscalant is attributed not only to its sorption properties, but mainly to its ability to block active sites of crystal growth.

3. Inhibitor sorption rate grows with scale formation rate increase.

4. In natural water inhibitor molecules are always chemically bonded with calcium ions and therefore do not adsorb on membrane surface. In cases where cal- cium is not contained in water (such as distilled water) antiscalant can adsorb on membrane surface.

5. Nucleation (formation of nuclei crystals) phase occurs without involvement of antiscalant even if antiscalant is added. After nucleus is formed its further growth is controlled by adsorption of inhibitor on the crystal surface.

\section{REFERENCES}

1. Reddy M.M., Nancollas G.H. Calcite crystal growth inhibition by phosphonates. Desalination. 1973; 12(1):61-73. DOI: 10.1016/s0011-9164(00)80175-7

2. Leung W.H., Nancollas G.H. Nitrilotri (methylenephosphonic acid) adsorption on barium sulfate crystals and its influence on crystal growth. Journal of crystal growth. 1978; 44(2):163-167. DOI: 10.1016/00220248(78)90190-2

3. Nielsen A.E. Kinetics of precipitation. Oxford, Pergamon Press, 1964; 153.

4. Weijnen M.P.C., van Rosmalen G.M. The influence of various polyelectrolytes on the precipitation of gypsum. Desalination. 1985; 54:239-261. DOI: 10.1016/0011-9164(85)80021-7

5. Cristoffersen M.R., Christoffersen J., Weijnen M.P.C., van Rosmalen G.M. Crystal growth of calcium sulphate dihydrate at low supersaturation. Journal of Crystal Growth. 1982; 58(3):585-595. DOI: 10.1016/0022-0248(82)90145-2

6. Tadros M.E., Mayes I. Linear growth rates of calcium sulfate dihydrate crystals in the presence of additives. Journal of Colloid and Interface Science. 1979; 72(2):245-254. DOI: 10.1016/0021-9797(79)90106-1

7. Solomon D.H., Rolfe P.F. Polymers that inhibit the deposition of calcium sulphate. Desalination. 1966; 1(3):260-266. DOI: 10.1016/s0011-9164(00)80257-x

8. Okazaki M., Kimura S. Effect of scale inhibitors in reverse osmosis process. Journal of Chemical Engineering of Japan. 1984; 17(2):216-218. DOI: 10.1252/ jcej.17.216

9. Borden J., Gilron J., Hasson D. Analysis of RO flux decline due to membrane surface blockage. Desalination. 1987; 66:257-269. DOI: 10.1016/00119164(87)90209-8

10. Jamaly S., Darwish N.N., Ahmed I., Hasan S.W. A short review on reverse osmosis pretreatment technologies. Desalination. 2014; 354:30-38. DOI: 10.1016/j. desal.2014.09.017

11. Goh P.S., Lau W.J., Othman M.H.D., Ismail A.F. Membrane fouling in desalination and its mitigation strategies. Desalination. 2018; 425:130-155. DOI: 10.1016/j.desal.2017.10.018

12. Jiang S., Li Y., Ladewig B.P. A review of reverse osmosis membrane fouling and control strategies.
Science of The Total Environment. 2017; 595:567-583. DOI: 10.1016/j.scitotenv.2017.03.235

13. Al-Roomi Y.M., Hussain K.F. Potential kinetic model for scaling and scale inhibition mechanism. Desalination. 2016; 393:186-195. DOI: 10.1016/j.desal.2015.07.025

14. Liu D., Dong W., Hui F. Lédion J. Comparative performance of polyepoxysuccinic acid and polyaspartic acid on scaling inhibition by static and rapid controlled precipitation methods. Desalination. 2012; 304:1-10. DOI: 10.1016/j.desal.2012.07.032

15. Pramanik B.K., Gao Y., Fan L., Roddick F.A., Liu Z. Antiscaling effect of polyaspartic acid and its derivative for RO membranes used for saline wastewater and brackish water desalination. Desalination. 2017; 404:224-229. DOI: 10.1016/j.desal.2016.11.019

16. Chaussemier M., Pourmohtasham E., Gelus D., Pecoul N., Perrot H., Ledion J. at al. State of art of natural inhibitors of calcium carbonate scaling. A review article. Desalination. 2015; 356:47-55. DOI: 10.1016/j. desal.2014.10.014

17. Li X., Hasson D., Shemer H. Flow conditions affecting the induction period of $\mathrm{CaSO}_{4}$ scaling on $\mathrm{RO}$ membranes. Desalination. 2018; 431:119-125. DOI: 10.1016/j.desal.2017.08.014

18. Borden J., Gilron J., Hasson D. Analysis of RO flux decline due to membrane surface blockage. Desalination. 1987; 66:257-269. DOI: 10.1016/00119164(87)90209-8

19. Okazaki M., Kimura S. Effect of scale inhibitors in reverse osmosis process. Journal of Chemical Engineering of Japan. 1984; 17(2):216-218. DOI: 10.1252/jcej.17.216

20. Pramanik B.K., Gao Y., Fan L., Roddick F.A., Liu Z. Antiscaling effect of polyaspartic acid and its derivative for RO membranes used for saline wastewater and brackish water desalination. Desalination. 2017; 404:224-229. DOI: 10.1016/j.desal.2016.11.019

21. Zimmer K., Hater W., Icart A., Jaworski J., Kruse N., Braun G. The performance of polycarboxylates as inhibitors for $\mathrm{CaCO} 3$ scaling in reverse osmosis plants. Desalination and Water Treatment. 2016; 57(4849):23162-23175. DOI: 10.1080/19443994.2015. 1133874 
22. Pervov A., Andrianov A., Rudakova G., Popov K. A comparative study of some novel "green" and traditional antiscalants efficiency for the reverse osmotic Black Sea water desalination. Desalination and Water Treatment. 2017; 73:11-21. DOI: 10.5004/ dwt.2017.20363

23. Ali S.A., Kazi I.W., Rahman F. Synthesis and evaluation of phosphate-free antiscalants to control $\mathrm{CaSO} 4 \cdot 2 \mathrm{H} 2 \mathrm{O}$ scale formation in reverse osmosis desalination plants. Desalination. 2015; 357:36-44. DOI: 10.1016/j.desal.2014.11.006

24. Pervov A.G. A simplified RO process design based on understanding of fouling mechanisms. Desalination. 1999; 126(1-3):227-247. DOI: 10.1016/s00119164(99)00179-4

25. Popov K., Oshchepkov M., Kamagurov S., Tkachenko S., Dikareva Ju., Rudakova G. Synthesis and properties of novel fluorescent-tagged polyacrylatebased scale inhibitors. Journal of Applied Polymer Science. 2017; 134(26). DOI: 10.1002/app.45017

26. Oshchepkov M., Kamagurov S., Tkachenko S., Ryabova A., Popov K. Insight into the mechanisms of scale inhibition: a case study of a task-specific fluorescent-tagged scale inhibitor location on gypsum crystals. ChemNanoMat. 2019; 5(5):586-592. DOI: 10.1002/ cnma.201800660

27. Rudakova G.Ya., Popov K.I., Oshhepkov M.S., Pervov A.G., Andrianov A.P. New domestic polymeric salt-removal inhibitors AMETEK RO-1 and AMETEK RO-2 to prevent the deposition of mineral salts in the desalination and desalination plants of seawater. Water treatment. Water treatment. Water supply. 2018; 2(122):60-65. (rus.).

28. Schmidt C.K., Brauch H.-J. Nowack B., VanBriesen J.M. Analysis of aminopolycarboxylates and organophosphonates. Biogeochemistry of Chelating
Agents. 2005; 76-97. DOI: 10.1021/bk-2005-0910. ch004

29. Shahid M.K., Choi Y.-G. The comparative study for scale inhibition on surface of RO membranes in wastewater reclamation: $\mathrm{CO}_{2}$ purging versus three different antiscalants. Journal of Membrane Science. 2018; 546:61-69. DOI: 10.1016/j.memsci.2017.09.087

30. Li C., Guo X., Wang X., Fan S., Zhou Q., Shao H. et al. Membrane fouling mitigation by coupling applied electric field in membrane system: Configuration, mechanism and performance. Electrochimica Acta. 2018; 287:124-134. DOI: 10.1016/j.electacta.2018.06.150

31. Shahid M.K., Pyo M., Choi Y.-G. The operation of reverse osmosis system with $\mathrm{CO}_{2}$ as a scale inhibitor: A study on operational behavior and membrane morphology. Desalination. 2018; 426:11-20. DOI: 10.1016/j.desal.2017.10.020

32. Popov K., Rudakova G., Larchenko V., Tusheva M., Afanas'eva, S. Kombarova E. et al. A comparative performance ranking of some phosphonates and environmentally friendly polymers on $\mathrm{CaCO}_{3}$ scaling inhibition by NACE protocol. Desalination and Water Treatment. 2017; 69:163-172. DOI: 10.5004/ dwt.2017.0336

33. Demadis K.D., Neofotistou E., Mavredaki E., Tsiknakis M., Sarigiannidou E.-M., Katarachia S.D. Inorganic foulants in membrane systems: chemical control strategies and the contribution of "green chemistry". Desalination. 2005; 179(1-3):281-295. DOI: 10.1016/j. desal.2004.11.074

34. Ying W., Siebdrath N., Uhl W., Gitis V., Herzberg M. New insights on early stages of RO membranes fouling during tertiary wastewater desalination. Journal of Membrane Science. 2014; 466:26-35. DOI: 10.1016/j. memsci.2014.04.027

Received January 21, 2019

Adopted in a modified form on February 22, 2019

Approved for publication May 27, 2019

B I o n o t e s : Val S. Frenkel — PhD, P.E., D.WRE, Vice President of Process Engineering, Managing Director Pacific Coast, GREELEY and HANSEN, 50 California st., suite 1500, San Francisco, California 94111, USA, vfrenkel@ greeley-hansen.com;

Alexey G. Pervov - Doctor of Technical Sciences, Professor, Professor of the Department of Water Supply and Sanitation, Moscow State University of Civil Engineering (National Research University) (MGSU), 26 Yaroslavskoe shosse, Moscow, 129337, Russian Federation, PervovAG@mgsu.ru;

Alexey P. Andrianov - PhD, Assistant Professor, Assistant Professor of the Department of Water Supply and Sanitation, Moscow State University of Civil Engineering (National Research University) (MGSU), 26 Yaroslavskoe shosse, Moscow, 129337, Russian Federation, AndrianovAP@mgsu.ru;

Vladimir A. Golovesov — postgraduate student of the Department of Water Supply and Sanitation, Moscow State University of Civil Engineering (National Research University) (MGSU), 26 Yaroslavskoe shosse, Moscow, 129337, Russian Federation, vive@mgsu.ru. 


\section{ЛИТЕРАТУРА}

1. Reddy M.M., Nancollas G.H. Calcite crystal growth inhibition by phosphonates // Desalination. 1973. Vol. 12. Issue 1. Pp. 61-73. DOI: 10.1016/s00119164(00)80175-7

2. Leung W.H., Nancollas G.H. Nitrilotri (methylenephosphonic acid) adsorption on barium sulfate crystals and its influence on crystal growth // Journal of Crystal Growth. 1978. Vol. 44. Issue 2. Pp. 163-167. DOI: $10.1016 / 0022-0248(78) 90190-2$

3. Nielsen A.E. Kinetics of precipitation. Oxford : Pergamon Press, 1964. P. 153.

4. Weijnen M.P.C., van Rosmalen G.M. The influence of various polyelectrolytes on the precipitation of gypsum // Desalination. 1985. Vol. 54. Pp. 239-261. DOI: $10.1016 / 0011-9164(85) 80021-7$

5. Cristoffersen M.R., Christoffersen J., Weijnen M.P.C., van Rosmalen G.M. Crystal growth of calcium sulphate dihydrate at low supersaturation // Journal of Crystal Growth. 1982. Vol. 58. Issue 3. Pp. 585-595. DOI: $10.1016 / 0022-0248(82) 90145-2$

6. Tadros M.E., Mayes I. Linear growth rates of calcium sulfate dihydrate crystals in the presence of additives // Journal of Colloid and Interface Science. 1979. Vol. 72. Issue 2. Pp. 245-254. DOI: 10.1016/00219797(79)90106-1

7. Solomon D.H., Rolfe P.F. Polymers that inhibit the deposition of calcium sulphate // Desalination. 1966 Vol. 1. Issue 3. Pp. 260-266. DOI: 10.1016/s00119164(00)80257-x

8. Okazaki M., Kimura S. Effect of scale inhibitors in reverse osmosis process // Journal of chemical engineering of Japan. 1984. Vol. 17. Issue 2. Pp. 216-218. DOI: 10.1252 /jcej. 17.216

9. Borden J., Gilron J., Hasson D. Analysis of RO flux decline due to membrane surface blockage // Desalination. 1987. Vol. 66. Pp. 257-269. DOI: 10.1016/00119164(87)90209-8

10. Jamaly S., Darwish N.N., Ahmed I., Hasan S.W. A short review on reverse osmosis pretreatment technologies // Desalination. 2014. Vol. 354. Pp. 30-38. DOI: 10.1016/j.desal.2014.09.017

11. Goh P.S., Lau W.J., Othman M.H.D., Ismail A.F. Membrane fouling in desalination and its mitigation strategies // Desalination. 2018. Vol. 425. Pp. 130-155. DOI: 10.1016/j.desal.2017.10.018

12. Jiang S., Li Y., Ladewig B.P. A review of reverse osmosis membrane fouling and control strategies // Science of The Total Environment. 2017. Vol. 595. Pp. 567-583. DOI: 10.1016/j.scitotenv.2017.03.235

13. Al-Roomi Y.M., Hussain K.F. Potential kinetic model for scaling and scale inhibition mechanism // Desalination. 2016. Vol. 393. Pp. 186-195. DOI: 10.1016/j. desal.2015.07.025
14. Liu D., Dong W., Hui F. Lédion J. Comparative performance of polyepoxysuccinic acid and polyaspartic acid on scaling inhibition by static and rapid controlled precipitation methods // Desalination. 2012. Vol. 304. Pp. 1-10. DOI: 10.1016/j.desal.2012.07.032

15. Pramanik B.K., Gao Y., Fan L., Roddick F.A., Liu $Z$. Antiscaling effect of polyaspartic acid and its derivative for RO membranes used for saline wastewater and brackish water desalination // Desalination. 2017. Vol. 404. Pp. 224-229. DOI: 10.1016/j.desal.2016.11.019

16. Chaussemier M., Pourmohtasham E., Gelus D., Pecoul N., Perrot H., Ledion J. et al. State of art of natural inhibitors of calcium carbonate scaling. A review article // Desalination. 2015. Vol. 356. Pp. 47-55. DOI: 10.1016/j.desal.2014.10.014

17. Li X., Hasson D., Shemer H. Flow conditions affecting the induction period of $\mathrm{CaSO}_{4}$ scaling on $\mathrm{RO}$ membranes // Desalination. 2018. Vol. 431. Pp. 119125. DOI: 10.1016/j.desal.2017.08.014

18. Borden J., Gilron J., Hasson D. Analysis of RO flux decline due to membrane surface blockage // Desalination. 1987. Vol. 66. Pp. 257-269. DOI: 10.1016/0011-9164(87)90209-8

19. Okazaki M., Kimura S. Effect of scale inhibitors in reverse osmosis process // Journal of Chemical Engineering of Japan. 1984. Vol. 17. Issue 2. Pp. 216218. DOI: $10.1252 /$ jcej.17.216

20. Pramanik B.K., Gao Y., Fan L., Roddick F.A., Liu $Z$. Antiscaling effect of polyaspartic acid and its derivative for RO membranes used for saline wastewater and brackish water desalination // Desalination. 2017. Vol. 404. Pp. 224-229. DOI: 10.1016/j.desal.2016.11.019

21. Zimmer K., Hater W., Icart A., Jaworski J., Kruse N., Braun $G$. The performance of polycarboxylates as inhibitors for $\mathrm{CaCO} 3$ scaling in reverse osmosis plants // Desalination and Water Treatment. 2016. Vol. 57. Issue 48-49. Pp. 23162-23175. DOI: 10.1080/19443994.2015.1133874

22. Pervov A., Andrianov A., Rudakova G., Popov $K$. A comparative study of some novel "green" and traditional antiscalants efficiency for the reverse osmotic Black Sea water desalination // Desalination and Water Treatment. 2017. Vol. 73. Pp. 11-21. DOI: 10.5004/ dwt.2017.20363

23. Ali S.A., Kazi I.W., Rahman F. Synthesis and evaluation of phosphate-free antiscalants to control $\mathrm{CaSO} 4 \cdot 2 \mathrm{H} 2 \mathrm{O}$ scale formation in reverse osmosis desalination plants // Desalination. 2015. Vol. 357. Pp. 36-44. DOI: $10.1016 /$ j.desal.2014.11.006

24. Pervov A.G. A simplified RO process design based on understanding of fouling mechanisms // Desal- 
ination. 1999. Vol. 126. Issue 1-3. Pp. 227-247. DOI: 10.1016/s0011-9164(99)00179-4

25. Popov K., Oshchepkov M., Kamagurov S., Tkachenko S., Dikareva Ju., Rudakova G. Synthesis and properties of novel fluorescent-tagged polyacrylatebased scale inhibitors // Journal of Applied Polymer Science. 2017. Vol. 134. Issue 26. DOI: 10.1002/app.45017

26. Oshchepkov M., Kamagurov S., Tkachenko S., Ryabova A., Popov K. Insight into the mechanisms of scale inhibition: a case study of a task-specific fluorescent-tagged scale inhibitor location on gypsum crystals // ChemNanoMat. 2019. Vol. 5. Issue 5. Pp. 586592. DOI: $10.1002 /$ cnma.201800660

27. Рудакова Г.Я., Попов К.И., Ощчепков М.С., Первов А.Г., Андрианов А.П. Новые отечественные полимерные ингибиторы солеотложений «АМЕТЕК PO-1» И «АМЕТЕК РО-2» для предотвращения отложения минеральных солей в установках обессоливания и опреснения морской воды // Водоочистка, водоподготовка, водоснабжение. 2018. № 2 (122). C. $60-65$.

28. Schmidt C.K., Brauch H.-J. Analysis of aminopolycarboxylates and organophosphonates // Biogeochemistry of Chelating Agents. 2005. Pp. 76-97. DOI: 10.1021/bk-2005-0910.ch004

29. Shahid M.K., Choi Y.-G. The comparative study for scale inhibition on surface of RO membranes in wastewater reclamation: $\mathrm{CO}_{2}$ purging versus three different antiscalants // Journal of Membrane Science. 2018. Vol. 546. Pp. 61-69. DOI: 10.1016/j.memsci.2017.09.087
30. Li C., Guo X., Wang X., Fan S., Zhou Q., Shao H. et al. Membrane fouling mitigation by coupling applied electric field in membrane system: Configuration, mechanism and performance // Electrochimica Acta. 2018. Vol. 287. Pp. 124-134. DOI: 10.1016/j. electacta.2018.06.150

31. Shahid M.K., Pyo M., Choi Y.-G. The operation of reverse osmosis system with $\mathrm{CO}_{2}$ as a scale inhibitor: A study on operational behavior and membrane morphology // Desalination. 2018. Vol. 426. Pp. 11-20. DOI: 10.1016/j.desal.2017.10.020

32. Popov K., Rudakova G., Larchenko V., Tusheva M., Afanas'eva, S. Kombarova E. et al. A comparative performance ranking of some phosphonates and environmentally friendly polymers on $\mathrm{CaCO}_{3}$ scaling inhibition by NACE protocol // Desalination and Water Treatment. 2017. Vol. 69. Pp. 163-172. DOI: 10.5004/ dwt.2017.0336

33. Demadis K.D., Neofotistou E., Mavredaki E., Tsiknakis M., Sarigiannidou E.-M., Katarachia S.D. Inorganic foulants in membrane systems: chemical control strategies and the contribution of "green chemistry" // Desalination. 2005. Vol. 179. Issue 1-3. Pp. 281-295. DOI: $10.1016 /$ j.desal.2004.11.074

34. Ying W., Siebdrath N., Uhl W., Gitis V., Herz$\operatorname{berg} M$. New insights on early stages of RO membranes fouling during tertiary wastewater desalination // Journal of Membrane Science. 2014. Pp. 26-35. DOI: 10.1016/j. memsci.2014.04.027

Поступила в редакиию 21 января 2019 г.

Принята в доработанном виде 22 февраля 2019 г.

Одобрена для публикаиии 27 мая 2019 г.

О Б А в т о РА Х: Френкель Вал С. - кандидат технических наук, инженер, дипломированный инженер по водным ресурсам, вице-президент по технологическому проектированию, управляющий директор (Тихоокеанское побережье), Грили и Хансен, 94111, США, Калифорния, г. Сан-Франциско, ул. Калифорния, д. 50, оф. 1500, vfrenkel@greeley-hansen.com;

Первов Алексей Германович - доктор технических наук, профессор, профессор кафедры водоснабжения и водоотведения, Национальный исследовательский Московский государственный строительный университет (НИУ МГСУ), 129337, г. Москва, Ярославское шоссе, д. 26, PervovAG@mgsu.ru;

Андрианов Алексей Петрович - кандидат технических наук, доцент, доцент кафедры водоснабжения и водоотведения, Национальный исследовательский Московский государственный строительный университет (НИУ МГСУ), 129337, г. Москва, Ярославское шоссе, д. 26, AndrianovAP@mgsu.ru;

Головесов Владимир Алексеевич - аспирант кафедры водоснабжения и водоотведения, Национальный исследовательский Московский государственный строительный университет (НИУ МГСУ), 129337, г. Москва, Ярославское шоссе, д. 26, vive@mgsu.ru. 